\title{
Neurog1, Neurod1, and Atoh1 are essential for spiral ganglia, cochlear nuclei, and cochlear hair cell development
}

\author{
Karen L. Elliott ${ }^{1}$ Gabriela Pavlinkova ${ }^{2} \quad$ Victor V. Chizhikov ${ }^{3}$ Ebenezer N. Yamoah ${ }^{4}$ Bernd Fritzsch ${ }^{1 *}$ \\ ${ }^{1}$ Department of Biology, University of Iowa, Iowa City, IA, USA \\ ${ }^{2}$ Institute of Biotechnology of the Czech Academy of Sciences, Vestec, Czechia \\ ${ }^{3}$ Department of Anatomy and Neurobiology, The University of Tennessee Health Science Center, Memphis, TN 38163, USA \\ ${ }^{4}$ Department of Physiology and Cell Biology, University of Nevada, Reno, NV, USA
}

\begin{abstract}
We review the molecular basis of three related basic helix-loop-helix (bHLH) genes (Neurogl, Neurod1, and Atohl) and upstream regulators Eya1/Six1, Sox2, Pax2, Gata3, Fgfr2b, Foxg1, and Lmx1a/b during the development of spiral ganglia, cochlear nuclei, and cochlear hair cells. Neuronal development requires early expression of Neurogl, followed by its downstream target Neurod1, which downregulates Atoh1 expression. In contrast, hair cells and cochlear nuclei critically depend on Atoh1 and require Neurod1 and Neurogl expression for various aspects of development. Several experiments show a partial uncoupling of Atoh1/Neurod1 (spiral ganglia and cochlea) and Atoh1/Neurog1/Neurod1 (cochlear nuclei). In this review, we integrate the cellular and molecular mechanisms that regulate the development of auditory system and provide novel insights into the restoration of hearing loss, beyond the limited generation of lost sensory neurons and hair cells.
\end{abstract}

\section{Keywords}

bHLH genes, cochlea development, neuronal differentiation, cochlear nuclei projections

\section{Peer Review}

The peer reviewers who approve this article are:

1. Matthew W Kelley, Laboratory of Cochlear Development, National Institute on Deafness and Other Communication Disorders, National Institutes of Health, Maryland, USA

Competing interests: No competing interests were disclosed.

2. Thomas Coate, Department of Biology, Georgetown University, Washington, DC, USA Competing interests: No competing interests were disclosed. 
*Corresponding author: Bernd Fritzsch (bernd-fritzsch@uiowa.edu)

Competing interests: The authors declare that they have no competing interests.

Grant information: This work was supported by National Institutes of Health/National Institute on Aging grants R01 AG060504 (KE, BF, and ENY), P01AG051443, and R01 DC016099R01 and DC05135 (ENY), the Czech Science Foundation (20-06927S) (GP), and the institutional support of the Czech Academy of Sciences RVO: 86652036 (GP).

The funders had no role in study design, data collection and analysis, decision to publish, or preparation of the manuscript.

Copyright: (C) 2021 Fritzsch B et al. This is an open access article distributed under the terms of the Creative Commons Attribution License, which permits unrestricted use, distribution, and reproduction in any medium, provided the original work is properly cited.

How to cite this article: Elliott KL, Pavlinkova G, Chizhikov VV, Yamoah EN and Fritzsch B. Neurog1, Neurod1, and Atoh1 are essential for spiral ganglia, cochlear nuclei, and cochlear hair cell development. Faculty Reviews 2021 10:(47) https://doi.org/10.12703/r/10-47

Published: 11 May 2021, Faculty Reviews 10:(47) https://doi.org/10.12703/r/10-47 


\section{Introduction}

Without a doubt, loss of hair cells, in combination with deprivation of sensory neurons and cochlear nuclei, results in severe aging-related hearing loss ${ }^{1-5}$. Various approaches to hearing restoration focus mostly on hair cell regeneration, often without a full appreciation of the apparent interaction of hair cells with sensory neurons and cochlear nuclei ${ }^{6-8}$. For instance, the loss of hair cells also reduces most, but not all, spiral ganglion neurons ${ }^{9-11}$. Furthermore, early loss of sensory neurons massively affects the cochlear nuclei ${ }^{12}$. Thus, the best way of approaching the development/regeneration of hair cells, sensory neurons, and cochlear nuclei neurons is to resolve their dependence on each other: how are the development of hair cells, sensory neurons, and cochlear nuclei related ${ }^{13-18}$ ?

Three basic helix-loop-helix (bHLH) genes were shown to be crucial for hair cell, sensory neuron, and cochlear nucleus development:

1. Neurog1 plays a crucial role in sensory neuron development, affects hair cells ${ }^{19,20}$, and has a limited impact on cochlear nuclei ${ }^{21}$.

2. Neurodl plays a role in neuronal differentiation, cochlear nucleus development, and hair cell development ${ }^{16,22,23}$.

3. Atohl is essential for cochlear hair cells and cochlear nuclei development ${ }^{24-26}$ and has a limited effect on sensory neurons $s^{27,28}$.

Sensory neurons exit the cell cycle from the base to the apex between embryonic day 10 (E10) and E12 in mice, followed by cochlear hair cells from the apex to base between E12 and E14 ${ }^{29}$. In parallel, cochlear nuclei exit the cell cycle between $\mathrm{E} 10$ and $\mathrm{E} 14^{30}$. Spiral ganglion neurons project to cochlear hair cells (from base to apex; E13-E16; Figure 1) and nearly simultaneously send central processes to cochlear nuclei

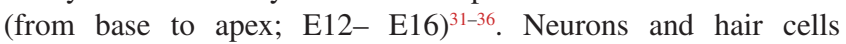
have been suggested to have a clonal relationship because of similarities in bHLH gene expression. This relationship may play a role in neuronal pathfinding for at least the periphery ${ }^{37}$; however, central targeting is less understood but may involve Neurod $1^{16}$.

Spiral ganglion neurons depend upon Neurogl ${ }^{19}$ and Neurod ${ }^{22}$. In contrast to Neurog1 null mice ${ }^{19}$, which showed a complete loss of neurons, Neurodl null mice ${ }^{23}$ showed residual spiral ganglion neurons extending centrally to smaller cochlear nuclei ${ }^{16,22}$. Unlike Neurog1, which is possibly transiently expressed in cochlear nuclei, Neurodl was found massively expressed, overlapping with Atohl ${ }^{26}, \operatorname{Ptfl}^{38,39}$, and Lmxla/b $b^{14,25}$. Peripherally, it was established that cochlear hair cells critically depend on Atohl (Mathl $)^{24}$. Furthermore, the length of the cochlea depends on Neurog $1^{19}$ and Neurod $1^{22,23}$. Neurogl is upstream of Neurod1 $1^{20}$, and both are upstream of Atoh $1^{28,40}$. Neurogl and Neurodl truncate Atohl expression ${ }^{19,27}$. Similarly, in the cerebellum, Neurodl negatively regulates Atoh $1^{41}$, suggesting that these genes interact in many areas of neuronal development. Also, a loss or reduction of cochlear hair cells occurs following the absence of $\operatorname{Gata}^{42}, \operatorname{Pax}^{43}$, Eyal/Six1 ${ }^{44}$, Foxg 1 15,46, and Lmxla ${ }^{47-49}$, and many of these genes and others also affect the sensory neurons innervating them ${ }^{31,42,43,50-53}$.

We will provide a comprehensive review of the interplay of the three bHLH genes (Neurog1, Neurodl, and Atohl) in the context of spiral ganglia, cochlear nuclei, and cochlear hair cells development. In addition, we will examine the role of other transcription factors (Eya1/Six1, Sox2, Pax2, Gata3, Foxg1, and Lmxla/b) known to be involved in their development.

\section{Spiral Ganglion Neurons}

Crosstalk of Neurog1, Neurod1, and Atoh1 determines inner ear sensory neuron fate

Both Neurogl and Neurodl play important roles in sensory neuron development and differentiation. All inner ear sensory neurons were lost in Neurog 1 null mice ${ }^{19}$. Similarly, many sensory neurons were lost in Neurodl null mice; however, not all neurons were lost $^{54}$. More recent work in Neurodl null mice showed that of those neurons that survived, there was an intermingled vestibular and auditory sensory neuron projection to cochlear hair cells ${ }^{16,27}$ and showed a reduced and aberrant central projection to cochlear nuclei ${ }^{10,16}$.

What is unknown is whether there is a direct role of Atohl in sensory neuron development or whether it is indirect. Hair cells depend on neuronal innervation for long-term maintenance ${ }^{55-57}$. Similarly, neurons depend on hair cells and supporting cells for their maintenance ${ }^{12}$. Logically, one would assume that the absence of hair cells will eventually cause degeneration of many neurons because of a lack of neurotrophic support. Atohl null mouse embryos, which lack hair cells, showed reduced Bdnf-lacZ staining and reduced hair cell innervation in the basal turn of the cochlea (Figure 2). The apex, which retained Bdnf-lacZ staining in undifferentiated cells of these mice, showed a denser spacing of spiral ganglion neurons, suggesting that Bdnf expression may not depend on Atohl in the apex ${ }^{58}$. Conditional deletion of Atohl resulted in residual innervation correlated to residual hair cell formation ${ }^{11,27}$, demonstrating that near-normal residual cochlear hair cells receive innervation from a surprisingly large number of neurons ${ }^{27}$. Pou4f3 (Brn33c) null mice, which develop only immature hair cells and have limited expression of neurotrophins ${ }^{59}$, show little effect on innervation patterns beyond the lack of innervation to outer hair cells (OHCs) birth. The absence of inner hair cells (IHCs), through the loss of Atohl or in Bronx-waltzer mutants, results in spiral ganglion projections to $\mathrm{OHCs}$ and disorganized central projections ${ }^{10,60,61}$ (Figure 2). Interestingly, replacing an allele of Atohl with Neurogl in Atohl $1^{\text {kiNeurogl }}$ mice showed a different pattern of spiral ganglia projections to reach out the organ of Corti $^{62,63}$ (Figure 2), consistent with a reduction in the number of neurons and hair cells ${ }^{16}$.

Furthermore, although Atohl/Neurodl double null mice have no differentiated hair cells, they retain cochlear nuclei and a diminished spiral ganglion with aberrant innervation ${ }^{27}$, suggesting 

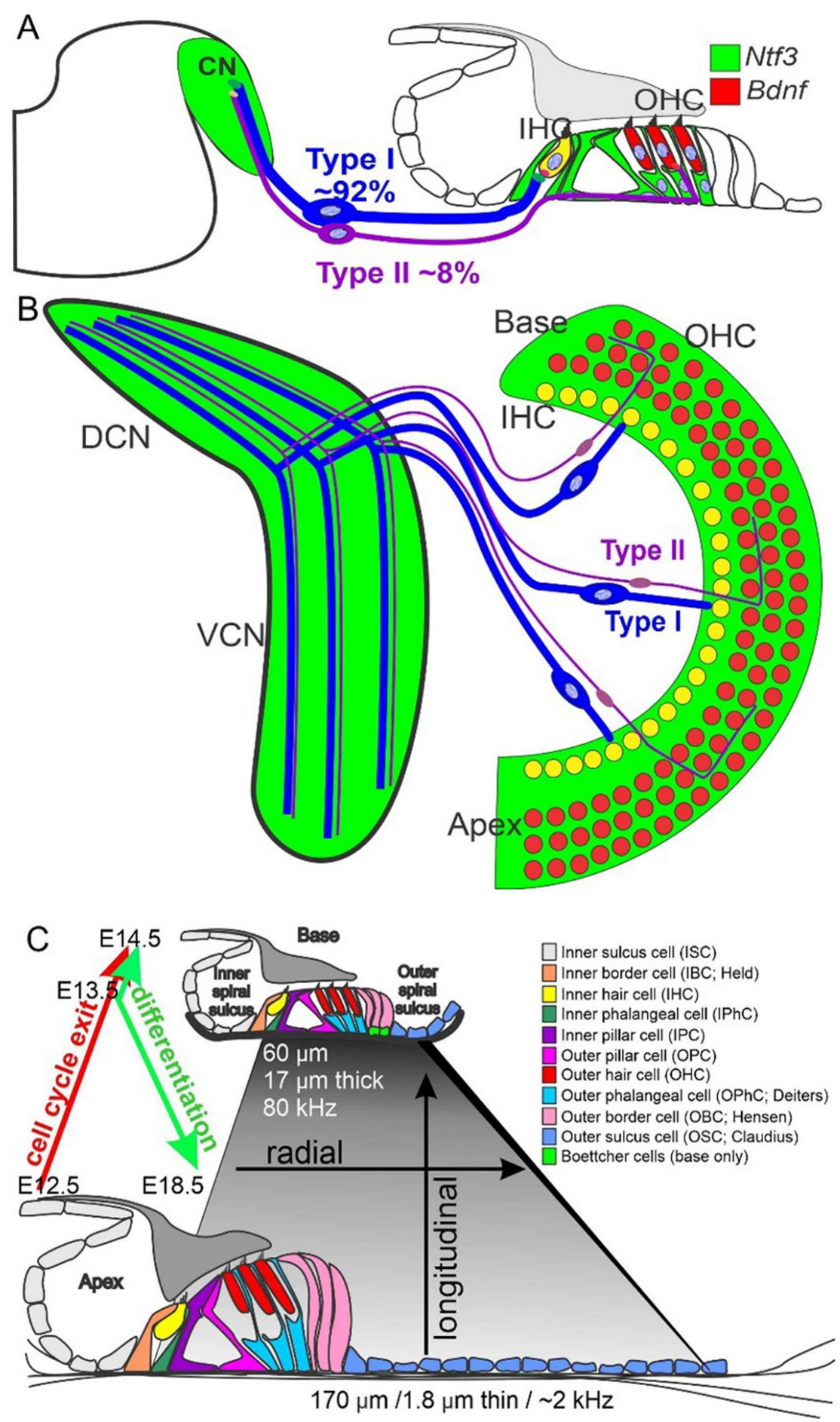

Figure 1. The auditory system revealed in development. Organization of the cochlear hair cells, the spiral ganglia, and the innervation of the cochlear nuclei $(\mathbf{A})$. Details show the differential innervation of spiral ganglion neurons to the inner hair cells (IHCs) (yellow, expresses both Ntf3 and brain-derived neurotrophic factor (BDNF)) and outer hair cells (OHCs) (red, expresses BDNF). Note that only Ntf3 (green) is expressed in cochlear nucleus neurons (B). After the apex-to-base cell cycle exit (E12.5-14.5), a base-to-apex differentiation of hair cells by Atoh 1 follows (E14.5-18.5) (C). In addition, differences in hair cells and supporting cells and the size and thickness of the organ of Corti are depicted $(\mathbf{C})$. DCN, dorsal cochlear nucleus; E, embryonic day; VCN, ventral cochlear nucleus. This figure was adapted with permission from Booth KT et al. ${ }^{64}$ under the terms of the Creative Commons 4.0 Attribution License (CC BY 4.0) (A and C) and from Rubel and Fritzsch $^{12}(\mathbf{B})$ 


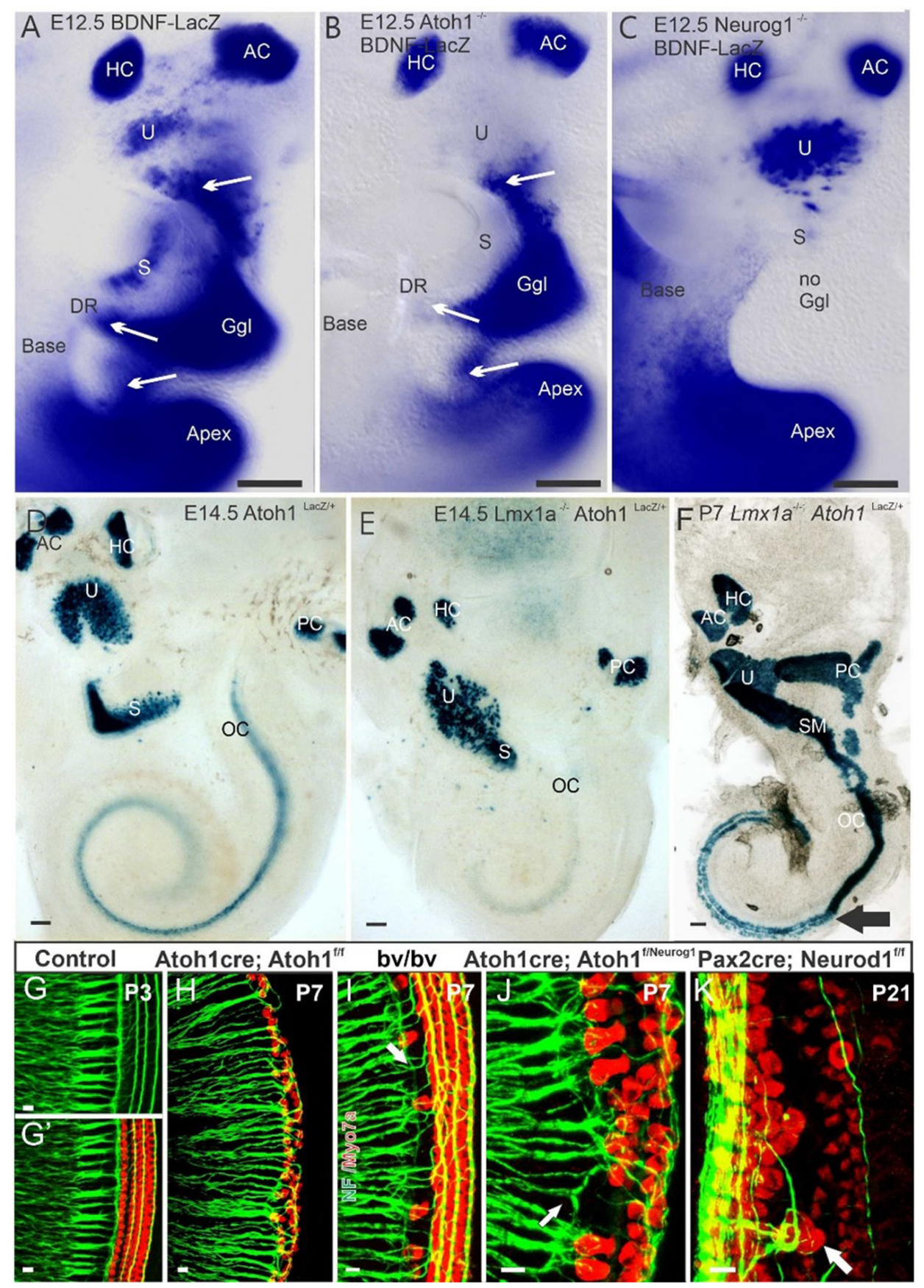

Figure 2. Spiral ganglion neurons depend primarily on Neurog1 for the development. BDNF-LacZ of control mice (A) is compared with Atoh 1tf; BDNFLacZ (B) and Neurog 1tff; BDNFLacZ (C). There is an absence of some, but not all, hair cells in Atoh1 null mice (A, B) and loss of sensory neurons and gain and loss of different hair cells in Neurog1 null mice (C). Atoh 1Lacz at embryonic day 14.5 (E14.5) shows nearcomplete hair cell development near the apex (D). In E14.5 Lmx1a-/- mutants, there is a delayed expression of Atoh 1Lacz (E). By postnatal day 7 (P7), the hair cells develop, but there is a fusion of the organ of Corti (OC) with the saccule (SM) (F). Detailed comparisons show normal inner ear afferents in controls (G, G'), reduced afferents in Atoh1-cre; Atoh 1/f "self-termination" (H), an expansion of afferents to outer hair cells in the absence of inner hair cells in Bronx waltzer (bv/bv) (I) and Atoh1-cre; Atoh $1^{\text {t/kineurog } 1}(\mathbf{J})$ mutants and altered innervation and cell type formation in Neurod1 conditional deletions (K) (arrows). AC, anterior canal crista; DR, ductus reuniens; Ggl, ganglion; HC, horizontal canal crista; P, postnatal day; PC, posterior canal crista; S, saccule; U, utricle. This figure was adapted with permission from Jahan et al. ${ }^{10}$ (A-C), from Matei et al. ${ }^{28}$ (D-F), and from Copyright Clearance Center: Springer Nature, Cell and Tissue Research, Nichols et al. ${ }^{49}$, Copyright (C) 2008, Springer-Verlag (G-K). 
an uncoupling of innervation and hair cell differentiation. The inactivation of both bHLH transcription factors in double Atoh1/Neurod1 null mutants uncouples fiber growth and expansion of remaining neurons ${ }^{27}$ that could be useful for hair cell restoration ${ }^{3,5,65,66}$. More recent data using Rosa ${ }^{\text {CreER }}$; Rainbow mice showed clones of spiral ganglion neurons and hair cells in the organ of Corti, suggesting that they arose from a typical progenitor cell ${ }^{67}$. Initially, the meaning of the transient expression of apparently cochlear-derived neurons was unclear.

In contrast to the loss of spiral ganglion neurons in mice lacking Neurog $1^{19,28}$, overexpression of Neurog1 in immortalized multipotent otic progenitors (a cellular system for spiral ganglion neuron differentiation) drives proliferation via increased $C d k 2$. It promotes neuronal differentiation through the expression of Neurod $1^{68}$. These findings suggest that Neurogl can promote proliferation or neuronal differentiation and possibly impact hair cells without affecting cochlear nuclei ${ }^{68,69}$. It appears that a set of data support the transformation of astrocytes into neurons in Neurod $1^{70}$ and Neurog $2^{71}$. The induction of neuronal proliferation and otic progenitor cell transplantation is a potential strategy to replace lost spiral ganglion neurons.

Recent work on the characterization of neuronal and hair cell progenitors revealed insights into early gene expression during neuronal development ${ }^{7,72}$. Markers for spiral ganglion neurons, Isl $I^{73,74}$ and Gata3 $3^{9,75,76}$, were detected in developing neurons, although Neurodl was seen in only the youngest neurons ${ }^{7}$.

In summary, the known deletion of spiral ganglion neurons in Neurodl and Neurog1 null mice ${ }^{27,28}$ suggests these as potential genes for the induction of new neurons with or without inducing hair cells $s^{7,68}$ and is consistent with predictions of various cell types that require independent inducers ${ }^{9,10}$. Understanding how the expansion of neuronal projections in the absence of hair cells could be helpful to restore lost innervation ${ }^{3,5,72,77,78}$, in particular, understanding how to reinnervate the flat epithelia after long-term hearing loss, will be beneficial ${ }^{79}$.

\section{Deletion of Sox2 and other genes affect spiral ganglion neuron development}

Initially, deletion of Sox 2 was thought to eliminate all sensory neurons ${ }^{80,81}$; however, a transient development of vestibular neurons was recently shown ${ }^{31}$. A delayed loss of Sox 2 in Isll-cre; So $\times 2^{\text {fff }}$ mice showed a transient development of spiral ganglion neurons with abnormal innervation to disorganized hair cells in the base but no hair cells or sensory neurons in the $\operatorname{apex}^{73}$. That the later-forming neurons in the apex never developed suggests that Sox 2 is essential for late neuronal development. Any similarities between different Sox 2 deletions (Lcc, Ysb, Isll-cre; Foxg1-cre) remain to be investigated. Eyal/ Six1 induces Sox 2 expression to promote proneurosensorylineage specification. Ablation of the ATPase-subunit Brgl or both Eyal/Sixl results in loss of Sox 2 expression and lack of neurosensory identity, leading to abnormal apoptosis within the otic ectoderm. Brgl binds to two of three distal $3^{\prime}$ Sox2 enhancers occupied by Sixl, and Brgl binding to these regions depends on Eyal/Sixl activity ${ }^{82}$. Recent work provides insight into SOX2 and NEUROD1 protein expression dynamics during neuronal differentiation. Quantification of the fluorescence intensity of nuclear proteins in immortalized multipotent otic progenitors showed expression dynamics of SOX2 and NEUROD1 from a progenitor into differentiated neurons. During neuronal differentiation, SOX2 levels decreased while NEUROD1 levels increased ${ }^{69}$. Evaluation of Neurog 1 was excluded because of its dual roles in both proliferation and neuronal differentiation $^{68}$. The increase of Neurodl expression is in line with what is known for Neurodl in collaboration with Sox $2^{10,31}$. Understanding the expression dynamics of crucial transcription factors helps design replacement strategies for lost sensory neurons ${ }^{69}$.

The deletion of Pax2 resulted in a near absence of spiral ganglion neurons ${ }^{43}$, comparable to the significant loss of spiral ganglion neurons in Isll-cre; Sox $2^{\text {ff }}$ mice $^{73}$. Many additional genes derail the development of the inner ear and its innervation ${ }^{9,83-86}$. For example, disorganized projections to the cochlea are shown with Sox10 deletion in Schwann cells ${ }^{87}$. In addition, partial loss of hair cells reorganizes the remaining afferents and efferents ${ }^{75,88,89}$. These data provide a baseline of various deficits that require further examination, including the disorganized innervation in conditional deletions of Gata3 $3^{9,32,90}$. Other genes, such as those involved in Wnt signaling, affect afferent innervation to $\mathrm{OHCs}^{85}$, but more work is needed to fine-tune the different effects. Finally, Lmxla loss results in a delayed upregulation of Atohl combined with a transformation of basal turn hair cells into a mix of cochlear and vestibular hair cells ${ }^{10,13}$. In summary, Sox 2 is essential for sensory neuron development $^{31}$ in combination with other downstream neuronal inducers (Neurogl and Neurod1) known to interact with Atoh $1^{16,27}$.

\section{Cochlear Nuclei}

Neurod1 and Atoh1 are expressed in the cochlear nuclei

Beyond a transient and limited expression of Neurog1 expression in vestibular nuclei ${ }^{21,91,92}$, the other bHLH genes, Atohl and Neurod1, are expressed in cochlear nuclei ${ }^{18,93,94}$. Atohl is expressed in developing cochlear nuclei, and the dorsal cochlear nucleus specifically requires Neurod1 ${ }^{22,23}$. Atohl is expressed dorsally in the central nervous system and its deletion disrupted spinal cord, brainstem, and cerebellum development ${ }^{95,96}$. Rhombomere-specific deletion of Atohl demonstrates that the cochlear nucleus forms from cells in rhombomeres 3-517,97. Atohl expression is negatively regulated by Neurodl in the cerebellum $^{41,98}$, the cochlear hair cells and neurons ${ }^{10}$, and the intestine $^{99}$ but has not yet been shown for the cochlear nucleus. An additional bHLH gene, $b H L H b 5^{97}$, is also necessary to properly form the dorsal cochlear nucleus. Both $b H L H b 5$ and another gene, Ptfla, are strongly expressed in the dorsal cochlear nucleus ${ }^{39,100}$; however, details on central projections for losing either of those two genes have not yet been provided ${ }^{94,101}$. Loss of Atohl or Ptfla resulted in a loss of excitatory or inhibitory 
cochlear nuclei neurons, respectively, suggesting that both genes are important for regulating cell fate determination ${ }^{38,39}$. Recent molecular work on Atohl and Ptfla lineage contributions to cochlear nuclei development show conserved and divergent origins across species ${ }^{15,102}$.

Neurodl deletion is shown to affect the central targeting of inner ear neurons massively. Not only are auditory neuron projections aberrant, but there is also an overlap of cochlear and vestibular projections ${ }^{16}$. Furthermore, the central projections are disorganized to the inferior colliculi ${ }^{16}$, expanding previous work on defects generated with Hoxb 2 mutants $^{103}$. In contrast, Atoh1 null mutants, which lack cochlear nuclei, show nearnormal central projections ${ }^{104}$, suggesting that neither Atohl nor the cochlear nuclei themselves have a notable role in afferent pathfinding centrally. The conditional deletion of Atohl in the ear, but retaining Atohl expression in cochlear nuclei, shows near-normal segregation of central projections ${ }^{27}$, expanding the critical independence of Atohl in neuronal pathfinding. Not surprisingly, then, Atohl/Neurodl double null mice had little additional disorganized projection of cochlear afferents beyond that of Neurodl alone ${ }^{27}$ (Figure 3). Atohl/Neurodl forms a complex interaction in the cerebellum ${ }^{41,98,105}$, which is useful for Neurodl to convert astrocytes and Schwann cells into neurons ${ }^{70,106,107}$. Details are needed to determine whether deviations of central projections (Figure 1) would occur in older stages after cochlear nuclei are formed ${ }^{30}$ and dependence of cochlear nuclei on neuronal input declines ${ }^{12}$. Recent data suggest plastic reinnervation of cochlear nuclei ${ }^{108}$, but it remains unclear whether this plasticity is permanent.

These data implicate several different bHLH genes (Atohl, Neurodl, Ptfla, and bHLHb5) in cochlear nuclei development. The interactions of these genes in cochlear nuclei development and innervation remain to be fully characterized.

\section{Sox2 and $L m x 1 a / b$ are expressed in cochlear nuclei}

Sox2 is essential for proneuronal regulation throughout the entire brain ${ }^{109,110}$ and is broadly expressed in cochlear nuclei, but its role has not been detailed by selective $\operatorname{Sox} 2$ deletion in cochlear nuclei. Lmxla/b double null mutants lack cochlear nuclei and choroid plexus and have a hindbrain reminiscent of a spinal cord $^{13}$. In these mice, central projections of spiral ganglion neurons are lost, and vestibular fibers project bilaterally to the dorsal hindbrain and interdigitate with contralateral vestibular fibers ${ }^{13}$. The presence of these bilateral projections correlated with the expression of other genes, such as Wnt $3 a$ and $T b r 2$. The suggested Wnt $3 a$ attraction expands on previous data showing that loss of the Wnt receptor, $F z d 3^{111}$, or downstream Wnt signaling component, Prickle $1^{86}$, affects central projections. Recent work suggests that another gene, Npr2, affects central projections, showing the gain and loss of afferents to different cochlear nuclei ${ }^{32,35}$.

In summary, the expression of $L m x l a / b$ for the proper formation of the hindbrain is essential and the deletion of $L m x l a / b$ causes aberrational projections. In contrast to the detailed description of Lmxla/b loss, there is limited information on the role of Sox 2 and other genes (Npr2, Prickle1, Fzd3, and Wnt $3 a$ ) on central projections.

\section{Cochlear Hair Cells}

Neurog1, Neurod1, and Atoh1 interaction in developing hair cells

Without a doubt, the development of all hair cells depends upon Atohl expression ${ }^{24}$. Atohl expression initiates in the cochlea at the upper-middle turn around E13.5 and progresses bilaterally toward the base and apex. Atohl expression shows a delayed upregulation in the apex compared with the base ${ }^{24,58}$, combined with very late apical hair cell differentiation at E18.5 ${ }^{112,113}$. Interestingly, inner pillar cells were positive for Atoh1, suggesting that Atohl expression does not always result in a hair cell fate 28,114 . In contrast to differentiation of hair cells starting near the base and progressing toward the apex, hair cells exit the cell cycle first in the apex, at E12.5, and progress toward the base $\mathrm{b}^{28,29,115}$. Furthermore, cell exit progresses radially from IHCs to $\mathrm{OHCs}^{10,116,117}$, as was shown initially using green fluorescent protein (GFP) labeling ${ }^{118}$. Loss of Neurog1 results in hair cells exiting the cell cycle two days earlier than controls $^{28}$. Furthermore, there is a premature Atohl upregulation in an atypical apex-to-base progression in hair cells following Neurog $1 \operatorname{loss}^{19,28}$. Likewise, in Neurod1 null mice, early upregulation of Atohl from apex to base resulted in the formation of IHC-like cells in the region of OHCs, suggesting a transformation of OHCs into IHCs because of increased Atohl expression $^{16,23}$. The cellular processes driving remodeling of the prosensory domain during cochlear development indicate that combinations of cellular growth contribute to base-to-apex cochlear extension, allowing different interpretations of $\mathrm{OHC}$ progression $^{10,88,116,117,119,120}$. Despite its prominent role in hair cell differentiation, Atohl (Figure 4) does not seem to have a role in cochlear length determination ${ }^{27}$. In contrast, Neurog 1 deletion resulted in a 50\% reduction in cochlear length, a reduction in the size of vestibular epithelia ${ }^{28}$, and ectopic hair cells in the utricle ${ }^{9,121}$. Likewise, loss of Neurodl (Figure 4) shortened the cochlea by about $50 \%{ }^{16,23}$. Atohl/Neurodl double knockout added minimally to the cochlear length reduction in Neurodl loss alone ${ }^{27}$. Although this suggests a possible interaction of bHLH genes, the reduction in length may be influenced simply by the loss of Shh normally generated by spiral ganglion neurons ${ }^{122}$, which would be absent or reduced in number in Neurogl or Neurodl null mice. The reduction of the organ of Corti is affected by several deletions of $S h h^{123}$, Gata $^{75}$, Foxg $1^{45,124}$, and Lmxla $a^{47,49}$ in addition to Neurog1 and Neurodl.

Conditional deletion of Atohl using Pax2-cre showed that most hair cells were lost during late embryonic development; however, some undifferentiated cells express Myo7a in postnatal stages and are targeted by neurons. A "self-terminating" system (Atohl-cre; Atohl ${ }^{\text {fff }}$ ), in which a transient expression of Atohl results in some initial hair cell development, demonstrated progressive loss of IHCs and most OHCs shortly after birth $^{11}$. However, some Myo7a-positive OHCs remained in adults in these mice. This suggests that most hair cells depend upon continued Atohl expression for at least some time. Various 


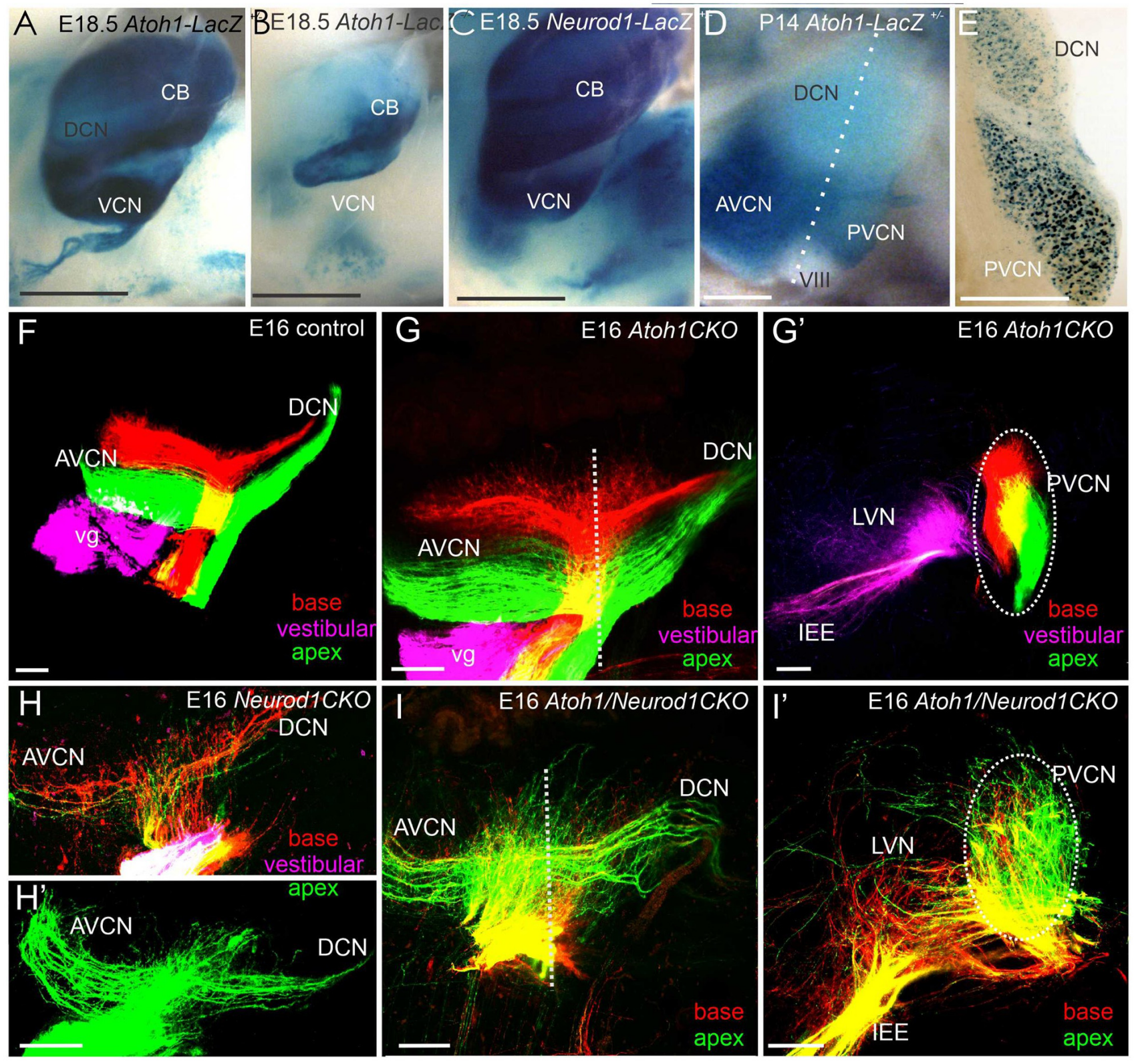

Figure 3. Atoh1 is expressed in the cochlear nuclei and the cerebellum for development. Loss of Atoh1 (Atoh 1LaczlacZ) results in the loss of the cerebellum and cochlear nuclei (A, B). Likewise, Neurod 1 is expressed in cochlear nuclei and cerebellum (C). It shows later differential expression in the dorsal cochlear nucleus (DCN) (low level of Atoh1; (D)) compared with the stronger expression of Neurod1 in the DCN (E), suggesting a negative feedback between Atoh1 and Neurod1. The central projection of sensory neurons is nearly identical between controls $(\mathbf{F})$ and Atoh 1 CKO mutants $\left(\mathbf{G}, \mathbf{G}^{\prime}\right)$. In contrast, both Neurod1 CKO $\left(\mathbf{H}, \mathbf{H}^{\prime}\right)$ and Atoh1/Neurod1 CKO mice $\left(\mathbf{I}, \mathbf{I}^{\prime}\right)$ show scrambled central projections. AVCN, anteroventral cochlear nucleus; CB, cerebellum; E, embryonic day; IEE, inner ear efferents; LVN, lateral vestibular nucleus; PVCN, posteroventral cochlear nucleus; VCN, ventral cochlear nucleus; vg, vestibular ganglion. This figure was adapted with permission from Fritzsch et al. ${ }^{11}$ under the terms of the Creative Commons 4.0 Attribution License (CC BY 4.0) (A-E), from Copyright Clearance Center: Springer Nature, Cell and Tissue Research, Pan et al. ${ }^{41}$, Copyright @ 2009 , Springer-Verlag (D,E), and from Copyright Clearance Center: Springer Nature, Molecular Biology, Filova et al..$^{27}$, Copyright $@ 2020$, Springer Nature $\left(\mathbf{F}-\mathbf{I}^{\prime}\right)$.

other conditional deletions of Atohl established that continued Atohl expression is essential for hair cell survival and maturation ${ }^{100,125}$. Interestingly, generating a transgenic mouse in which Neurogl replaces Atohl (Atohl $1^{\text {kiNeurogl/kiNeurogl) }}$ showed that, although Neurogl cannot fully rescue the Atohl null hair cell loss phenotype, it does form additional patches of undifferentiated "hair cells" rather than a flat epithelium ${ }^{63}$. In addition, heterozygote mice expressing one copy of each gene 

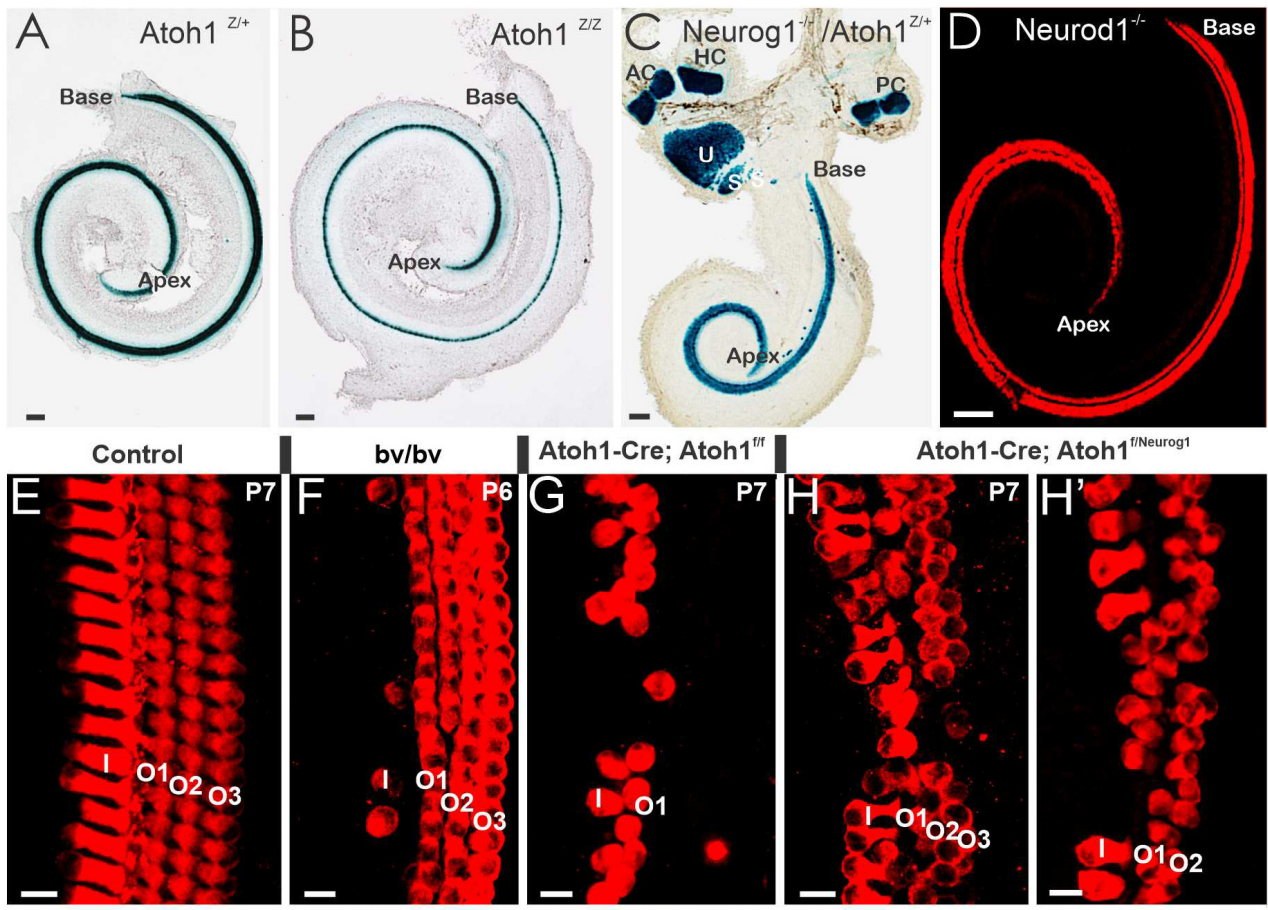

bv/bv
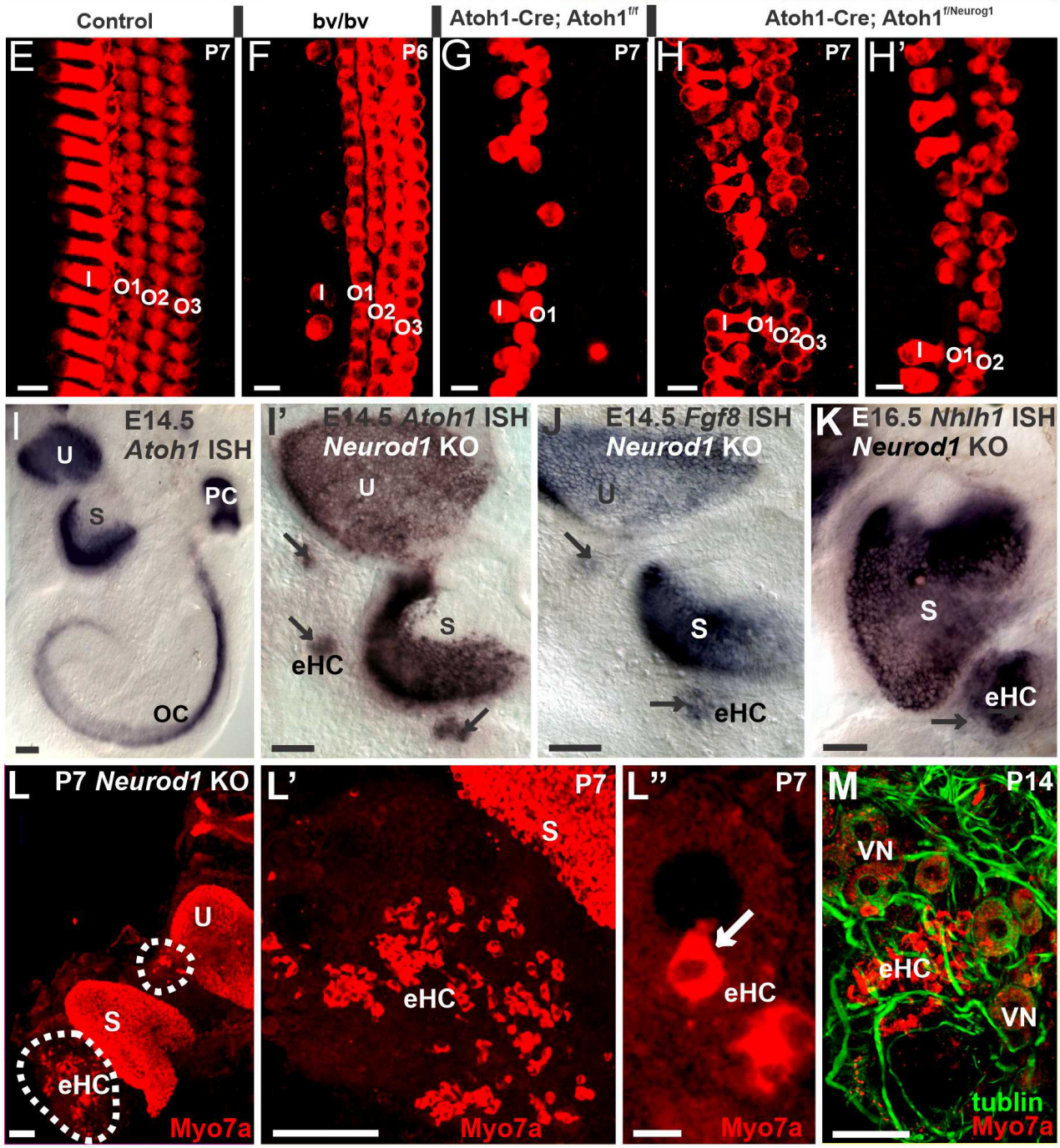

Figure 4. Expressed of Atoh1 is needed for cochlear hair cells for development. Loss of Atoh1 has a limited effect of cochlea extension $(\mathbf{A}, \mathbf{B})$ compared with the shortened cochlea in Neurog1(C) and Neurod1 (D) null mice. Detailed images compare control hair cells $(\mathbf{E})$ within

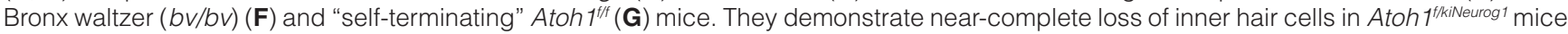
$\left(\mathbf{H}, \mathbf{H}^{\prime}\right)$, demonstrating incomplete development of different sets of hair cells. Expression of Atoh1 in situ hybridization (ISH) depends on the normal expression pattern in control end organs (I). Ectopic "hair cells" after Neurod1 deletion are shown with ISH for Atoh1, Fgf8, and NhIh1 $\left(\mathbf{I}^{\prime}, \mathbf{J}, \mathbf{K}\right)$. Hair cells within vestibular epithelia (L) as well as ectopic hair cells (L-L", arrow in L") are positive for Myo7a. Myo7a labeling also shows ectopic hair cells innervated by tubulin-labeled vestibular neurons (VN) (M). AC, anterior canal crista; eHC, ectopic hair cells; HC, horizontal canal crista; P, passage; PC, posterior canal crista; S, saccule; U, utricle. Bar indicates $100 \mu \mathrm{m}\left(\mathbf{A}-\mathbf{L}^{\prime}, \mathbf{M}\right)$ and $10 \mu \mathrm{m}\left(\mathbf{L}^{\prime \prime}\right)$. This figure was modified after Fritzsch et al. ${ }^{58}(\mathbf{A}, \mathbf{B})$ and was adapted with permission from Matei et al..$^{28}(\mathbf{C})$, from Jahan et al. ${ }^{54}$ under the terms of the Creative Commons Attribution License (D, I-M), and from Booth KT et al. ${ }^{64}$ under the terms of the Creative Commons 4.0 Attribution License (CC BY 4.0) (E-H'). 
(Atoh1 kiNeurogl/+) showed some disorganization of hair cell distribution (Figure 2 and Figure 4) not observed in Atohl heterozygotes, suggesting cross-interaction between Atohl and Neurog1. Using an ingenious system to overexpress Atohl, in which the Atohl coding sequence is under the control of a tetracycline response element (TRE), generated viable ectopic "hair cells" in early postnatal mice ${ }^{126}$ in line with an upper induction of proliferation ${ }^{127}$.

Loss of Neurodl resulted in the formation of Atohl-positive "hair cell"-like cells within intraganglionic vesicles (Figure 4) in the vestibular ganglion ${ }^{54}$, suggesting a potential conversion of vestibular sensory neurons into hair cells. The ectopic hair cells are forming in addition to the saccule and utricle and are positive for several genes-such as Atohl, Fgf8, and Nhlhlthat generally are expressed outside the hair cells (Figure 4). This finding indicates the normal suppression of Atohl by Neurod1 in these neurons and implies that Neurodl might suppress hair cell fate in sensory neurons ${ }^{16}$. Similar Neurod1-Atohl interactions were reported in the cerebellum ${ }^{41,98}$ and the intestine ${ }^{99}$ and were used to transform astrocytes to neurons ${ }^{106,107}$. In the absence of both Atohl and Neurodl in double null mutants, these "ectopic hair cells" are not formed ${ }^{27}$, suggesting that Neurodl and Atohl interact upregulate neurons into ectopic hair cells after the loss of Neurod1.

In summary, using progenitor cells for spiral ganglia and hair cell replacement seems to be a possible way forward for hearing restoration ${ }^{7,68}$, in addition to various other approaches ${ }^{6,8,77,128}$. Unfortunately, generation of new hair cells in later stages beyond the earliest stages has not yet been achieved ${ }^{127}$. Understanding how to generate new hair cells at later stages is needed for older animals and humans with aging-related hearing $\operatorname{loss}^{1,2}$. Fully understanding the various mutations and putting them into the context of different cell fates require identifying certain steps necessary to initiate specific distributions of sensory hair cells ${ }^{10,113,129,130}$. What remains is understanding the various interactions of Neurog1, Neurod1, and Atoh1 for the complete formation of all hair cells.

\section{Sox2 interacts with other genes for hair cell expression}

Sox 2 is also essential for hair cell formation ${ }^{52}$, likely through the activation of Atohl expression ${ }^{109,110,131}$. Interestingly, two independent approaches using delayed deletion of $\operatorname{Sox} 2^{53,73,131}$ showed different results. In one, a delayed loss of Sox 2 using Sox2-cre-ER demonstrated effects in the apex only ${ }^{131}$. In the other study, conditional deletion of Sox 2 using Islet1-cre resulted in the loss of hair cells in the apex and a delayed loss in the base, showing unusual basal turn hair cells/supporting cells and inner pillar cells ${ }^{73}$, suggesting a role for the timing of Sox2 expression. As expected, the timing of Sox 2 expression was later demonstrated to be essential for sensory development ${ }^{81,132}$. Furthermore, a complete deletion of Sox 2 in the ear using Foxg1-cre showed the overall cochlear reduction and no hair cell development ${ }^{31}$. These combined studies provide an essential role of Sox2, although the interaction of Sox2 with Atoh1 is not fully understood $6,8,68,76,77,88,117$.

Other genes are also crucial for inner ear and hair cell development. For example, Eyal/Sixl is essential for early ear development and is needed to form the cochlea $a^{44,50,53}$ and induces Sox2 expression, as described earlier ${ }^{82}$. Another gene, Pax2, is necessary for organ-of-Corti formation ${ }^{43}$ and cooperates with Sox2 to activate Atohl expression ${ }^{51}$. Conditional deletion of Gata3 using Pax2-cre showed deletion of many hair cells and a complete loss of all hair cells with an earlier deletion of Gata3 using Foxg1-cre ${ }^{42,75}$. In these latter mice, levels of Atohl expression were significantly reduced, and genes downstream of Atohl were not detected following this early deletion of Gata3. Mice mutant for another gene, Lmxla, showed a delayed expression of Atohl followed by transforming some organ-of-

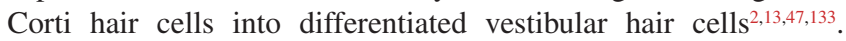
Foxg1 null mice show a reduced cochlear length and a disorganized apex of multiple rows of hair cells with disoriented polarities ${ }^{45,46,124,134}$. A somewhat similar phenotype is reported for $n-M y c$ null mutants accompanied with apical cell fate changes ${ }^{46,57,135-137}$.

The partial deletion of some, but not other, hair cells is an exciting perspective that needs to be explored. Inactivation of Fgfrl in the inner ear by Foxgl-Cre-mediated deletion leads to an $85 \%$ reduction in the number of auditory hair cells ${ }^{138}$. Likewise, Sox 2 omission shows a partial loss of hair cells in the Yellow submarine $(Y s b)$ mutation $^{52}$. Using Pax2-cre to conditionally delete Dicer $^{89}$ resulted in incomplete hair cell loss compared with the total hair cell loss with Foxg1-cre conditional deletion, comparable to the equivalent conditional deletions of Gata3 ${ }^{75,139}$. Finally, Bronx-waltzer mice, which are mutant for the gene Srrm4 (Figure 4), lose IHCs and vestibular hair cells but retain $\mathrm{OHCs}^{60,61}$. OHCs, meanwhile, express Srrm3 independent of the Srrm4 gene downstream of REST ${ }^{61}$.

These data show that cochlear hair cells are affected by single gene deletions and complex interactions of several genes, including compound analysis of partial deletions ${ }^{10}$, primarily unexplored in detail ${ }^{7,72}$. While Atohl alone is the dominant gene ${ }^{24}$, interactions with other genes need to be worked out $^{44,77,78}$.

\section{Summary and conclusion}

Inner ear sensory neurons, cochlear nuclei, and cochlear hair cells all require bHLH genes for their proper development. Atohl is essential for cochlear hair cell and cochlear nuclei development. Neurogl and Neurodl are vital for sensory neuron development and differentiation. All three genes play crucial roles in a feedback network to regulate specific cell fate appropriately and in coordination with other genes. Some of these additional genes interact with the bHLH genes in these contexts, such as $L m x l a / b$, requiring more detailed investigation. 
1. Dubno JR: New Insights on Age-Related Hearing Loss. J S C Acad Sci. 2019; 17: 3 Reference Source

2. Hoffman HJ, Dobie RA, Losonczy KG, et al:: Declining Prevalence of Hearing Loss in US Adults Aged 20 to 69 Years. JAMA Otolaryngol Head Neck Surg. 2017; 143(3): 274-85

PubMed Abstract | Publisher Full Text | Free Full Tex

3. Liberman MC: Noise-induced and age-related hearing loss: new perspectives and potential therapies [version 1; peer review: 4 approved]. F100ORes. 2017; 6: 927.

PubMed Abstract | Publisher Full Text | Free Full Text

4. Schilder AGM, Su MP, Blackshaw H, et al:: Hearing Protection, Restoration, and Regeneration: An Overview of Emerging Therapeutics for Inner Ear and Central Hearing Disorders. Otol Neurotol. 2019; 40(5): 559-70.

PubMed Abstract | Publisher Full Text | Faculty Opinions Recommendation

5. Yamoah EN, Li M, Shah A, et al.: Using Sox2 to alleviate the hallmarks of agerelated hearing loss. Ageing Res Rev. 2020; 59: 101042. PubMed Abstract | Publisher Full Text | Free Full Text

6. Lenz DR, Gunewardene N, Abdul-Aziz DE, et al.: Applications of Lgr5Positive Cochlear Progenitors (LCPs) to the Study of Hair Cell Differentiation. Front Cell Dev Biol. 2019; 7: 14

PubMed Abstract | Publisher Full Text | Free Full Text |

Faculty Opinions Recommendation

7. Roccio M, Perny M, Ealy M, et al:: Molecular characterization and prospective isolation of human fetal cochlear hair cell progenitors. Nat Commun. 2018; 9(1): 4027.

PubMed Abstract | Publisher Full Text | Free Full Text |

Faculty Opinions Recommendation

8. Yamashita T, Zheng F, Finkelstein D, et al:: High-resolution transcriptional dissection of in vivo Atoh1-mediated hair cell conversion in mature cochleae identifies IsI1 as a co-reprogramming factor. PLOS Genet. 2018; 14(7): e1007552.

PubMed Abstract | Publisher Full Text | Free Full Text

9. Duncan JS, Cox BC: Anatomy and Development of the Inner Ear. In: Fritzsch, B. (Ed.), The senses. Elsevier, 2021; 253-275.

10. Jahan I, Elliott KL, Fritzsch B: Understanding Molecular Evolution and Development of the Organ of Corti Can Provide Clues for Hearing Restoration. Integr Comp Biol. 2018; 58(2): 351-65.

PubMed Abstract | Publisher Full Text | Free Full Text

11. Pan N, Jahan I, Kersigo J, et al:: A novel Atoh1 "self-terminating" mouse model reveals the necessity of proper Atoh1 level and duration for hair cell differentiation and viability. PLOS One. 2012; 7(1): e30358. PubMed Abstract | Publisher Full Text | Free Full Text

12. Rubel EW, Fritzsch B: Auditory system development: Primary auditory neurons and their targets. Annu Rev Neurosci. 2002; 25: 51-101.

PubMed Abstract | Publisher Full Text

13. Chizhikov VV, Iskusnykh IY, Fattakhov N, et al.: $L m x 1 a$ and $L m x 1 b$ are Redundantly Required for the Development of Multiple Components of the Mammalian Auditory System. Neuroscience. 2021; 452: 247-64. PubMed Abstract | Publisher Full Text | Free Full Text

14. Glover JC, Elliott KL, Erives A, et al.: Wilhelm His' lasting insights into hindbrain and cranial ganglia development and evolution. Dev Biol. 2018; 444 Suppl 1(Suppl 1): S14-S24.

PubMed Abstract | Publisher Full Text | Free Full Text

15. Lipovsek M, Wingate RJ: Conserved and divergent development of brainstem vestibular and auditory nuclei. eLife. 2018; 7: e40232. PubMed Abstract | Publisher Full Text | Free Full Text

16. Macova I, Pysanenko K, Chumak T, et al:: Neurod1 Is Essential for the Primary Tonotopic Organization and Related Auditory Information Processing in the Midbrain. J Neurosci. 2019; 39(6): 984-1004.

PubMed Abstract | Publisher Full Text | Free Full Text

17. Maricich SM, Xia A, Mathes EL, et al:: Atoh1-lineal neurons are required for hearing and for the survival of neurons in the spiral ganglion and brainstem accessory auditory nuclei. J Neurosci. 2009; 29(36): 11123-33. PubMed Abstract | Publisher Full Text | Free Full Text

18. Nothwang HG: Evolution of mammalian sound localization circuits: A developmental perspective. Prog Neurobiol. 2016; 141: 1-24. PubMed Abstract | Publisher Full Text

19. Ma Q, Anderson DJ, Fritzsch B: Neurogenin 1 null mutant ears develop fewer, morphologically normal hair cells in smaller sensory epithelia devoid of innervation. J Assoc Res Otolaryngol. 2000; 1(2): 129-43. PubMed Abstract | Publisher Full Text | Free Full Text

20. Ma Q, Chen Z, Barrantes IdB, et al.: Neurogenin1 Is Essential for the Determination of Neuronal Precursors for Proximal Cranial Sensory Ganglia. Neuron. 1998; 20(3): 469-82. PubMed Abstract | Publisher Full Text

21. Guillermo B: Uncovering the interplay between call fate specification and progenitor dynamics during the development of the lower rhombic lip.
Universitat Pompeu Fabra. 2019

Reference Source

22. Kim WY, Fritzsch B, Serls A, et al.: NeuroD-null mice are deaf due to a severe loss of the inner ear sensory neurons during development. Development. 2001; 128(3): 417-26.

PubMed Abstract | Free Full Text

23. Liu M, Pereira FA, Price SD, et al.: Essential role of BETA2/NeuroD1 in development of the vestibular and auditory systems. Genes Dev. 2000; 14(22): 2839-54.

PubMed Abstract | Publisher Full Text | Free Full Text

24. Bermingham NA, Hassan BA, Price SD, et al:: Math1: An essential gene for the generation of inner ear hair cells. Science. 1999; 284(5421): 1837-41. PubMed Abstract | Publisher Full Text

25. Mishima Y, Lindgren AG, Chizhikov VV, et al:: Overlapping function of Lmx1a and $L m x 1 b$ in anterior hindbrain roof plate formation and cerebellar growth. J Neurosci. 2009; 29(36): 11377-84.

PubMed Abstract | Publisher Full Text | Free Full Text

26. Wang VY, Rose MF, Zoghbi HY: Math1 expression redefines the rhombic lip derivatives and reveals novel lineages within the brainstem and cerebellum. Neuron. 2005; 48(1): 31-43.

PubMed Abstract | Publisher Full Text

27. Filova I, Dvorakova M, Bohuslavova R, et al:: Combined Atoh1 and Neurod 1 Deletion Reveals Autonomous Growth of Auditory Nerve Fibers. Mol Neurobiol. 2020; 57(12): 5307-23.

PubMed Abstract | Publisher Full Text | Free Full Text

28. Matei V, Pauley S, Kaing S, et al:: Smaller inner ear sensory epithelia in Neurog 1 null mice are related to earlier hair cell cycle exit. Dev Dyn. 2005; 234(3): 633-50.

PubMed Abstract | Publisher Full Text | Free Full Text

29. Ruben RJ: Development of the inner ear of the mouse: A radioautographic study of terminal mitoses. Acta Otolaryngol. 1967; Suppl 220: 1-44. PubMed Abstract

30. Pierce ET: Histogenesis of the dorsal and ventral cochlear nuclei in the mouse. An autoradiographic study. J Comp Neurol. 1967; 131(1): 27-54 PubMed Abstract | Publisher Full Text

31. Dvorakova M, Macova I, Bohuslavova R, et al:: Early ear neuronal development, but not olfactory or lens development, can proceed without SOX2. Dev Biol. 2020; 457(1): 43-56.

PubMed Abstract | Publisher Full Text | Free Full Text

32. Goodrich LV: Early Development of the Spiral Ganglion. In: Dabdoub, A., Fritzsch, B., Popper, A.N., Fay, R.R. (Eds.), The Primary Auditory Neurons of the Mammalian Cochlea. Springer New York, New York, NY, 2016; 11-48. Publisher Full Text

33. Groves AK, Fekete DM: Shaping sound in space: The regulation of inner ear patterning. Development. 2012; 139(2): 245-57. PubMed Abstract | Publisher Full Text | Free Full Text

34. Groves AK, Fekete DM: New Directions in Cochlear Development. Understanding the Cochlea. Springer, 2017; 33-73. Publisher Full Text

35. Schmidt $H$, Fritzsch B: Npr2 null mutants show initial overshooting followed by reduction of spiral ganglion axon projections combined with near-norma cochleotopic projection. Cell Tissue Res. 2019; 378(1): 15-32. PubMed Abstract | Publisher Full Text | Free Full Text

36. Yang $\mathrm{T}$, Kersigo J, Jahan I, et al:: The molecular basis of making spiral ganglion neurons and connecting them to hair cells of the organ of Corti. Hear Res. 2011; 278(1-2): 21-33.

PubMed Abstract | Publisher Full Text | Free Full Text

37. Maklad A, Kamel S, Wong E, et al.: Development and organization of polarityspecific segregation of primary vestibular afferent fibers in mice. Cell Tissue Res. 2010; 340(2): 303-21.

PubMed Abstract | Publisher Full Text | Free Full Text

38. Fujiyama T, Yamada M, Terao M, et al:: Inhibitory and excitatory subtypes of cochlear nucleus neurons are defined by distinct bHLH transcription factors, Ptf1a and Atoh1. Development. 2009; 136(12): 2049-58. PubMed Abstract | Publisher Full Text

39. Iskusnykh IY, Steshina EY, Chizhikov VV: Loss of Ptf1a Leads to a Widespread Cell-Fate Misspecification in the Brainstem, Affecting the Development of Somatosensory and Viscerosensory Nuclei. J Neurosci. 2016; 36(9): 2691-710. PubMed Abstract | Publisher Full Text | Free Full Text

40. Raft S, Groves AK: Segregating neural and mechanosensory fates in the developing ear: Patterning, signaling, and transcriptional control. Cell Tissue Res. 2015; 359(1): 315-32.

PubMed Abstract | Publisher Full Text | Free Full Text

41. Pan N, Jahan I, Lee JE, et al.: Defects in the cerebella of conditional Neurod1 null mice correlate with effective $\mathrm{Tg}$ (Atoh1-cre) recombination and granule cell requirements for Neurod1 for differentiation. Cell Tissue Res. 2009; 337(3): 407-28.

PubMed Abstract | Publisher Full Text | Free Full Text 
42. Karis A, Pata I, van Doorninck JH, et al:: Transcription factor GATA-3 alters pathway selection of olivocochlear neurons and affects morphogenesis of the ear. J Comp Neurol. 2001; 429(4): 615-30. PubMed Abstract | Publisher Full Text

43. Bouchard M, de Caprona D, Busslinger M, et al.: Pax2 and Pax8 cooperate in mouse inner ear morphogenesis and innervation. BMC Dev Biol. 2010; 10: 89. PubMed Abstract | Publisher Full Text | Free Full Text

44. Ahmed M, Wong EYM, Sun J, et al:: Eya1-Six1 interaction is sufficient to induce hair cell fate in the cochlea by activating Atoh1 expression in cooperation with Sox2. Dev Cell. 2012; 22(2): 377-90. cooperation with Sox2. Dev Cell. 2012; 22(2): 377-90.
PubMed Abstract | Publisher Full Text | Free Full Text | Faculty Opinions Recommendation

45. Pauley S, Lai E, Fritzsch B: Foxg1 is required for morphogenesis and histogenesis of the mammalian inner ear. Dev Dyn. 2006; 235(9): 2470-82. PubMed Abstract | Publisher Full Text | Free Full Text

46. Zhang S, Zhang Y, Dong Y, et al.: Knockdown of Foxg1 in supporting cells increases the trans-differentiation of supporting cells into hair cells in the neonatal mouse cochlea. Cell Mol Life Sci. 2020; 77(7): 1401-19. PubMed Abstract | Publisher Full Text | Free Full Text | Faculty Opinions Recommendation

47. Huang Y, Hill J, Yatteau A, et al:: Reciprocal Negative Regulation Between Lmx1a and Lmo4 Is Required for Inner Ear Formation. J Neurosci. 2018; 38(23) 5429-40.

PubMed Abstract | Publisher Full Text | Free Full Text

48. Mann ZF, Gálvez H, Pedreno D, et al:: Shaping of inner ear sensory organs through antagonistic interactions between Notch signalling and Lmx1a. eLife. 2017; 6: e33323.

PubMed Abstract | Publisher Full Text | Free Full Text

49. Nichols $\mathrm{DH}$, Pauley $\mathrm{S}$, Jahan I, et al.: $\operatorname{Lm\times 1a}$ is required for segregation of sensory epithelia and normal ear histogenesis and morphogenesis. Cell Tissue Res. 2008; 334(3): 339-58.

PubMed Abstract | Publisher Full Text | Free Full Text

50. Ahmed M, Xu J, Xu PX: EYA1 and SIX1 drive the neuronal developmental program in cooperation with the SWI/SNF chromatin-remodeling complex and SOX2 in the mammalian inner ear. Development. 2012; 139(11): 1965-77. PubMed Abstract | Publisher Full Text | Free Full Text | Faculty Opinions Recommendation

51. Kempfle JS, Edge AS: Pax2 and Sox2 Cooperate to Promote Hair Cell Fate in Inner Ear Stem Cells. Otolaryngol Head Neck Surg. 2014; 151(1_suppl): P221-P221. Publisher Full Text

52. Kiernan $\mathrm{AE}$, Pelling $\mathrm{AL}$, Leung $\mathrm{KKH}$, et al.: Sox2 is required for sensory organ development in the mammalian inner ear. Nature. 2005; 434(7036): 1031-5. PubMed Abstract | Publisher Full Text

53. Li J, Zhang T, Ramakrishnan A, et al:: Dynamic changes in cis-regulatory occupancy by Six 1 and its cooperative interactions with distinct cofactors drive lineage-specific gene expression programs during progressive differentiation of the auditory sensory epithelium. Nucleic Acids Res. 2020; 48(6): 2880-96.

PubMed Abstract | Publisher Full Text | Free Full Text

54. Jahan I, Pan N, Kersigo J, et al.: Neurod1 suppresses hair cell differentiation in ear ganglia and regulates hair cell subtype development in the cochlea. PLoS One. 2010; 5(7): e11661.

PubMed Abstract | Publisher Full Text | Free Full Text |

Faculty Opinions Recommendation

55. Herranen A, Ikäheimo K, Lankinen T, et al.: Deficiency of the ER-stress-regulator MANF triggers progressive outer hair cell death and hearing loss. Cell Death Dis. 2020; 11(2): 100 PubMed Abstract | Publisher Full Text | Free Full Text

56. Kersigo J, Fritzsch B: Inner ear hair cells deteriorate in mice engineered to have no or diminished innervation. Front Aging Neurosci. 2015; 7: 33. PubMed Abstract | Publisher Full Text | Free Full Text

57. Schimmang T, Pirvola U: Coupling the cell cycle to development and regeneration of the inner ear. Semin Cell Dev Biol. 2013; 24(5): 507-13. PubMed Abstract | Publisher Full Text

58. Fritzsch B, Matei VA, Nichols DH, et al:: Atoh1 null mice show directed afferent fiber growth to undifferentiated ear sensory epithelia followed by incomplete fiber retention. Dev Dyn. 2005; 233(2): 570-83.

PubMed Abstract | Publisher Full Text | Free Full Text

59. Xiang M, Maklad A, Pirvola $U$, et al.: Brn3c null mutant mice show long-term, incomplete retention of some afferent inner ear innervation. BMC Neurosci. 2003; 4: 2.

PubMed Abstract | Publisher Full Text | Free Full Text

60. Nakano $Y$, Jahan I, Bonde G, et al: A mutation in the Srrm4 gene causes alternative splicing defects and deafness in the Bronx waltzer mouse. PLOS Genet. 2012; 8(10): e1002966.

PubMed Abstract | Publisher Full Text | Free Full Text

61. Nakano Y, Wiechert S, Fritzsch B, et al.: Inhibition of a transcriptional repressor rescues hearing in a splicing factor-deficient mouse. Life Sci. Alliance. 2020; 3(12): e202000841.

PubMed Abstract | Publisher Full Text | Free Full Text
62. Jahan I, Pan N, Kersigo J, et al.: Expression of Neurog1 instead of Atoh1 can partially rescue organ of Corti cell survival. PLoS One. 2012; 7(1): e30853. PubMed Abstract | Publisher Full Text | Free Full Text

63. Jahan I, Pan N, Kersigo J, et al:: Neurog1 can partially substitute for Atoh1 function in hair cell differentiation and maintenance during organ of Corti development. Development. 2015; 142(16): 2810-21.

PubMed Abstract | Publisher Full Text | Free Full Text

64. Booth KT, Azaiez H, Jahan I, et al.: Intracellular Regulome Variability Along the Organ of Corti: Evidence, Approaches, Challenges, and Perspective. Front Genet. 2018; 9: 156.

PubMed Abstract | Publisher Full Text | Free Full Text

65. Daudet N, Żak M: Notch Signalling: The Multitask Manager of Inner Ear Development and Regeneration. Adv Exp Med Biol. 2020; 1218: 129-57. PubMed Abstract | Publisher Full Text | Faculty Opinions Recommendation

66. Gnedeva K, Wang X, McGovern MM, et al.: Organ of Corti size is governed by Yap/Tead-mediated progenitor self-renewal. Proc Natl Acad Sci U S A. 2020; 117(24): 13552-61.

PubMed Abstract | Publisher Full Text | Free Full Text |

Faculty Opinions Recommendation

67. X Xu J, Ueno $\mathrm{H}, \mathrm{Xu} \mathrm{CY}$, et al.: Identification of mouse cochlear progenitors that develop hair and supporting cells in the organ of Corti. Nat Commun. 2017; 8: 15046 .

PubMed Abstract | Publisher Full Text | Free Full Text |

Faculty Opinions Recommendation

68. Song Z, Jadali A, Fritzsch B, et al.: NEUROG1 Regulates CDK2 to Promote Proliferation in Otic Progenitors. Stem Cell Reports. 2017; 9(5): 1516-29. PubMed Abstract | Publisher Full Text | Free Full Text

69. Song Z, Laureano AS, Patel K, et al:: Single-Cell Fluorescence Analysis of Pseudotemporal Ordered Cells Provides Protein Expression Dynamics for Neuronal Differentiation. Front Cell Dev Biol. 2019; 7: 87. PubMed Abstract | Publisher Full Text | Free Full Text | Faculty Opinions Recommendation

70. Liu MH, Li W, Zheng JJ, et al.: Differential neuronal reprogramming induced by NeuroD1 from astrocytes in grey matter versus white matter. Neural Regen Res. 2020; 15(2): 342-51.

PubMed Abstract | Publisher Full Text | Free Full Text | Faculty Opinions Recommendation

71. Liu F, Zhang Y, Chen F, et al:: Neurog2 directly converts astrocytes into functional neurons in midbrain and spinal cord. Cell Death Dis. 2021; 12(3): 225

PubMed Abstract | Publisher Full Text | Free Full Text | Faculty Opinions Recommendation

72. Roccio M, Senn P, Heller S: Novel insights into inner ear development and regeneration for targeted hearing loss therapies. Hear Res. 2020; 397: 107859. PubMed Abstract | Publisher Full Text | Faculty Opinions Recommendation

73. Dvorakova M, Jahan I, Macova I, et al.: Incomplete and delayed Sox2 deletion defines residual ear neurosensory development and maintenance. Sci Rep. 2016; 6: 38253.

PubMed Abstract | Publisher Full Text | Free Full Text

74. Radde-Gallwitz K, Pan L, Gan L, et al.: Expression of Islet1 marks the sensory and neuronal lineages in the mammalian inner ear. J Comp Neurol. 2004; 477(4): 412-21.

PubMed Abstract | Publisher Full Text | Free Full Text

75. Duncan JS, Fritzsch B: Continued expression of GATA3 is necessary for cochlear neurosensory development. PLoS One. 2013; 8(4): e62046. PubMed Abstract | Publisher Full Text | Free Full Text

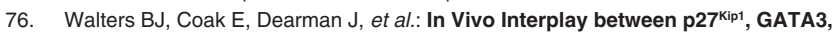
ATOH1, and POU4F3 Converts Non-sensory Cells to Hair Cells in Adult Mice. Cell Rep. 2017; 19(2): 307-20.

PubMed Abstract | Publisher Full Text | Free Full Text

77. Lopez-Juarez A, Lahlou H, Ripoll C, et al.: Engraftment of Human Stem Cell-Derived Otic Progenitors in the Damaged Cochlea. Mol Ther. 2019; 27(6): 1101-13.

PubMed Abstract | Publisher Full Text | Free Full Text | Faculty Opinions Recommendation

78. Zine A, Messat $Y$, Fritzsch B: A human induced pluripotent stem cell-based modular platform to challenge sensorineural hearing loss. Stem Cells. 2021. PubMed Abstract | Publisher Full Text

79. Shibata SB, Cortez SR, Beyer LA, et al.: Transgenic BDNF induces nerve fiber regrowth into the auditory epithelium in deaf cochleae. Exp Neurol. 2010; 223(2): 464-72.

PubMed Abstract | Publisher Full Text | Free Full Text

80. Puligilla C, Dabdoub A, Brenowitz SD, et al:: Sox2 induces neuronal formation in the developing mammalian cochlea. J Neurosci. 2010; 30(2): 714-22. PubMed Abstract | Publisher Full Text | Free Full Text

81. Steevens AR, Sookiasian DL, Glatzer JC, et al.: SOX2 is required for inner ear neurogenesis. Sci Rep. 2017; 7(1): 4086 PubMed Abstract | Publisher Full Text | Free Full Text

82. $\mathrm{Xu} \mathrm{J}, \mathrm{Li} \mathrm{J}$, Zhang $\mathrm{T}$, et al.: Chromatin remodelers and lineage-specific factors 
interact to target enhancers to establish proneurosensory fate within otic ectoderm. Proc Natl Acad Sci U S A. 2021; 118(12): e2025196118. PubMed Abstract | Publisher Full Text | Free Full Text

83. Coate TM, Kelley MW: Making connections in the inner ear: Recent insights into the development of spiral ganglion neurons and their connectivity with sensory hair cells. Semin Cell Dev Biol. 2013; 24(5): 460-9.

PubMed Abstract | Publisher Full Text | Free Full Text

84. Fritzsch B, Dillard M, Lavado A, et al:: Canal cristae growth and fiber extension to the outer hair cells of the mouse ear require Prox1 activity. PLoS One. 2010; 5(2): e9377.

PubMed Abstract | Publisher Full Text | Free Full Text

85. Ghimire SR, Deans MR: Frizzled3 and Frizzled6 Cooperate with Vangl2 to Direct Cochlear Innervation by Type II Spiral Ganglion Neurons. J Neurosci. 2019; 39(41): 8013-23.

PubMed Abstract | Publisher Full Text | Free Full Text |

Faculty Opinions Recommendation

86. Yang T, Kersigo J, Wu S, et al:: Prickle1 regulates neurite outgrowth of apical spiral ganglion neurons but not hair cell polarity in the murine cochlea. PLOS One. 2017; 12(8): e0183773.

PubMed Abstract | Publisher Full Text | Free Full Text

87. Mao Y, Reiprich S, Wegner M, et al.: Targeted deletion of Sox10 by Wnt1-cre defects neuronal migration and projection in the mouse inner ear. PLOS One. 2014; 9(4): e94580.

PubMed Abstract | Publisher Full Text | Free Full Text

88. Driver EC, Northrop A, Kelley MW: Cell migration, intercalation and growth regulate mammalian cochlear extension. Development. 2017; 144(20): 3766-76. PubMed Abstract | Publisher Full Text | Free Full Text

89. Soukup GA, Fritzsch B, Pierce ML, et al.: Residual microRNA expression dictates the extent of inner ear development in conditional Dicer knockout mice. Dev Biol. 2009; 328(2): 328-41.

PubMed Abstract | Publisher Full Text | Free Full Text

90. Fritzsch B, Elliott KL: Gene, cell, and organ multiplication drives inner ear evolution. Dev Biol. 2017; 431(1): 3-15.

PubMed Abstract | Publisher Full Text | Free Full Text

91. Fritzsch B, Pauley S, Feng F, et al:: The molecular and developmental basis of the evolution of the vertebrate auditory system. International Journal of Comparative Psychology. 2006; 19(1): 1-25.

Reference Source

92. Gálvez H, Abelló G, Giraldez F: Signaling and Transcription Factors during Inner Ear Development: The Generation of Hair Cells and Otic Neurons. Front Cell Dev Biol. 2017; 5: 21.

PubMed Abstract | Publisher Full Text | Free Full Text

93. Di Bonito M, Studer M, Puelles L: Nuclear derivatives and axonal projections originating from rhombomere 4 in the mouse hindbrain. Brain Struct Funct. 2017; 222(8): 3509-42. PubMed Abstract | Publisher Full Text | Free Full Text | Faculty Opinions Recommendation

94. Hernandez-Miranda LR, Müller T, Birchmeier C: The dorsal spinal cord and hindbrain: From developmental mechanisms to functional circuits. Dev Biol. 2017; 432(1): 34-42.

PubMed Abstract | Publisher Full Text | Faculty Opinions Recommendation

95. Bermingham NA, Hassan BA, Wang VY, et al.: Proprioceptor Pathway Development Is Dependent on MATH1. Neuron. 2001; 30(2): 411-22. PubMed Abstract | Publisher Full Text

96. Ray RS, Dymecki SM: Rautenlippe Redux -- toward a unified view of the precerebellar rhombic lip. Curr Opin Cell Biol. 2009; 21(6): 741-7. PubMed Abstract | Publisher Full Text | Free Full Text

97. Cai X, Kardon AP, Snyder LM, et al:: Bhlhb5::flpo allele uncovers a requirement for Bhlhb5 for the development of the dorsal cochlear nucleus. Dev Biol. 2016 414(2): 149-60.

PubMed Abstract | Publisher Full Text | Free Full Text

98. Kersigo J, Gu L, Xu L, et al:: Effects of Neurod1 Expression on Mouse and Human Schwannoma Cells. Laryngoscope. 2021; 131(1): E259-E270. PubMed Abstract | Publisher Full Text | Free Full Text

99. Li HJ, Ray SK, Pan N, et al:: Intestinal Neurod1 expression impairs paneth cell differentiation and promotes enteroendocrine lineage specification. $S c i$ Rep. 2019; 9(1): 19489.

PubMed Abstract | Publisher Full Text | Free Full Text

100. Cai T, Seymour ML, Zhang H, et al:: Conditional deletion of Atoh1 reveals distinct critical periods for survival and function of hair cells in the organ of Corti. J Neurosci. 2013; 33(24): 10110-22.

PubMed Abstract | Publisher Full Text | Free Full Text |

Faculty Opinions Recommendation

101. Dennis DJ, Han S, Schuurmans C: bHLH transcription factors in neural development, disease, and reprogramming. Brain Res. 2019; 1705: 48-65. PubMed Abstract | Publisher Full Text | Faculty Opinions Recommendation

102. Lunde A, Okaty BW, Dymecki SM, et al.: Molecular Profiling Defines Evolutionarily Conserved Transcription Factor Signatures of Major
Vestibulospinal Neuron Groups. eNeuro. 2019; 6(1): ENEURO.0475-18.2019. PubMed Abstract | Publisher Full Text | Free Full Text | Faculty Opinions Recommendation

103. Karmakar K, Narita Y, Fadok J, et al.: Hox2 Genes Are Required for Tonotopic Map Precision and Sound Discrimination in the Mouse Auditory Brainstem. Cell Rep. 2017; 18(1): 185-197.

PubMed Abstract | Publisher Full Text | Faculty Opinions Recommendation

104. Elliott KL, Kersigo J, Pan N, et al.: Spiral Ganglion Neuron Projection Development to the Hindbrain in Mice Lacking Peripheral and/or Central Target Differentiation. Front Neural Circuits. 2017; 11: 25 PubMed Abstract | Publisher Full Text | Free Full Text

105. Miyata T, Maeda T, Lee JE: NeuroD is required for differentiation of the granule cells in the cerebellum and hippocampus. Genes Dev. 1999; 13(13): 1647-52. PubMed Abstract | Publisher Full Text | Free Full Text

106. Chen YC, Ma NX, Pei ZF, et al.: A NeuroD1 AAV-Based Gene Therapy for Functional Brain Repair after Ischemic Injury through In Vivo Astrocyte-toNeuron Conversion. Mol Ther. 2020; 28(1): 217-234. PubMed Abstract | Publisher Full Text | Free Full Text | Faculty Opinions Recommendation

107. Ge LJ, Yang FH, Li W, et al.: In vivo Neuroregeneration to Treat Ischemic Stroke Through NeuroD1 AAV-Based Gene Therapy in Adult Non-human Primates. Front Cell Dev Biol. 2020; 8: 590008. PubMed Abstract | Publisher Full Text | Free Full Text | Faculty Opinions Recommendation

108. Ryugo DK, Kretzmer EA, Niparko JK: Restoration of auditory nerve synapses in cats by cochlear implants. Science. 2005; 310(5753): 1490-2. PubMed Abstract | Publisher Full Text | Faculty Opinions Recommendation

109. Cheah KSE, Xu PX: SOX2 in Neurosensory Fate Determination and Differentiation in the Inner Ear. Sox2. Elsevier, 2016; 263-280. Publisher Full Text

110. Kageyama R, Shimojo H, Ohtsuka T: Dynamic control of neural stem cells by bHLH factors. Neurosci Res. 2019; 138: 12-18. PubMed Abstract | Publisher Full Text | Faculty Opinions Recommendation

111. Duncan JS, Fritzsch B, Houston DW, et al:: Topologically correct central projections of tetrapod inner ear afferents require Fzd3. Sci Rep. 2019; 9(1): 10298. PubMed Abstract | Publisher Full Text | Free Full Text | Faculty Opinions Recommendation

112. Chen $P$, Johnson JE, Zoghbi HY, et al.: The role of Math1 in inner ear development: Uncoupling the establishment of the sensory primordium from hair cell fate determination. Development. 2002; 129(10): 2495-505. PubMed Abstract | Publisher Full Text | Faculty Opinions Recommendation

113. Menendez L, Trecek T, Gopalakrishnan S, et al.: Generation of inner ear hair cells by direct lineage conversion of primary somatic cells. eLife. 2020; 9 e55249.

PubMed Abstract | Publisher Full Text | Free Full Text |

Faculty Opinions Recommendation

114. Driver EC, Sillers L, Coate TM, et al:: The Atoh1-lineage gives rise to hair cells and supporting cells within the mammalian cochlea. Dev Biol. 2013; 376(1): 86-98.

PubMed Abstract | Publisher Full Text | Free Full Text

115. Lee YS, Liu F, Segil N: A morphogenetic wave of p27Kip1 transcription directs cell cycle exit during organ of Corti development. Development. 2006; 133(15): 2817-26.

PubMed Abstract | Publisher Full Text

116. Kopecky BJ, Jahan I, Fritzsch B: Correct timing of proliferation and differentiation is necessary for normal inner ear development and auditory hair cell viability. Dev Dyn. 2013; 242(2): 132-47. PubMed Abstract | Publisher Full Text | Free Full Text

117. Tateya T, Sakamoto S, Ishidate F, et al:: Three-dimensional live imaging of Atoh1 reveals the dynamics of hair cell induction and organization in the developing cochlea. Development. 2019; 146(21): dev177881. PubMed Abstract | Publisher Full Text | Faculty Opinions Recommendation

118. Zuo J, Treadaway J, Buckner TW, et al.: Visualization of alpha9 acetylcholine receptor expression in hair cells of transgenic mice containing a modified bacterial artificial chromosome. Proc Natl Acad Sci U S A. 1999; 96(24): 14100-5.

PubMed Abstract | Publisher Full Text | Free Full Text

119. Kempfle JS, Nguyen K, Hamadani C, et al:: Bisphosphonate-Linked TrkB Agonist: Cochlea-Targeted Delivery of a Neurotrophic Agent as a Strategy for the Treatment of Hearing Loss. Bioconjug Chem. 2018; 29(4): 1240-1250. PubMed Abstract | Publisher Full Text | Free Full Text

120. McLean WJ, Yin X, Lu L, et al:: Clonal Expansion of Lgr5-Positive Cells from Mammalian Cochlea and High-Purity Generation of Sensory Hair Cells. Cell Rep. 2017; 18(8): 1917-1929.

PubMed Abstract | Publisher Full Text | Free Full Text 
121. Raft S, Koundakjian EJ, Quinones H, et al.: Cross-regulation of Ngn1 and Math1 coordinates the production of neurons and sensory hair cells during inner ear development. Development. 2007; 134(24): 4405-15. PubMed Abstract | Publisher Full Text

122. Liu Z, Owen T, Zhang L, et al.: Dynamic expression pattern of Sonic hedgehog in developing cochlear spiral ganglion neurons. Dev Dyn. 2010; 239(6): 1674-83.

PubMed Abstract | Publisher Full Text | Free Full Text

123. Riccomagno MM, Takada S, Epstein DJ: Wnt-dependent regulation of inner ear morphogenesis is balanced by the opposing and supporting roles of Shh Genes Dev. 2005; 19(13): 1612-23.

PubMed Abstract | Publisher Full Text | Free Full Text | Faculty Opinions Recommendation

124. Hwang $\mathrm{CH}$, Simeone A, Lai $\mathrm{E}$, et al.: Foxg1 is required for proper separation and formation of sensory cristae during inner ear development. Dev Dyn. 2009; 238(11): 2725-34.

PubMed Abstract | Publisher Full Text

125. Chonko KT, Jahan I, Stone J, et al: Atoh1 directs hair cell differentiation and survival in the late embryonic mouse inner ear. Dev Biol. 2013; 381(2): 401-10. PubMed Abstract | Publisher Full Text | Free Full Text

126. Kelly MC, Chang Q, Pan A, et al:: Atoh1 directs the formation of sensory mosaics and induces cell proliferation in the postnatal mammalian cochlea in vivo. J Neurosci. 2012; 32(19): 6699-710. PubMed Abstract | Publisher Full Text | Free Full Text | Faculty Opinions Recommendation

127. White PM, Doetzlhofer A, Lee YS, et al:: Mammalian cochlear supporting cells can divide and trans-differentiate into hair cells. Nature. 2006; $441(7096)$ : 984-7.

PubMed Abstract | Publisher Full Text | Faculty Opinions Recommendation

128. Zhang J, Wang Q, Abdul-Aziz D, et al.: ERBB2 signaling drives supporting cell proliferation in vitro and apparent supernumerary hair cell formation in vivo in proliferation in vitro and apparent supernumerary hair cell formation in PubMed Abstract | Publisher Full Text | Free Full Text

129. Dabdoub A, Nishimura K: Cochlear Implants Meet Regenerative Biology: State of the Science and Future Research Directions. Otol Neurotol. 2017; 38(8): e232-e236. PubMed Abstract | Publisher Full Text

130. Samarajeewa A, Jacques BE, Dabdoub A: Therapeutic Potential of Wnt and
Notch Signaling and Epigenetic Regulation in Mammalian Sensory Hair Cell Regeneration. Mol Ther. 2019; 27(5): 904-11.

PubMed Abstract | Publisher Full Text | Free Full Text |

Faculty Opinions Recommendation

131. Kempfle JS, Turban JL, Edge ASB: Sox2 in the differentiation of cochlear progenitor cells. Sci Rep. 2016; 6: 23293.

PubMed Abstract | Publisher Full Text | Free Full Text

132. Steevens AR, Glatzer JC, Kellogg CC, et al:: SoX2 is required for inner ear growth and cochlear nonsensory formation before sensory development. Development. 2019; 146(13): dev170522. PubMed Abstract | Publisher Full Text | Free Full Text Faculty Opinions Recommendation

133. Nichols DH, Bouma JE, Kopecky BJ, et al.: Interaction with ectopic cochlear crista sensory epithelium disrupts basal cochlear sensory epithelium development in Lmx1a mutant mice. Cell Tissue Res. 2020; 380(3): 435-48. PubMed Abstract | Publisher Full Text | Free Full Text

134. Dastidar SG, Landrieu PMZ, D'Mello SR: FoxG1 promotes the survival of postmitotic neurons. J Neurosci. 2011; 31(2): 402-13. PubMed Abstract | Publisher Full Text | Free Full Text

135. Domínguez-Frutos E, López-Hernández I, Vendrell V, et al:: $\mathbf{N}$ - $m$ yc controls proliferation, morphogenesis, and patterning of the inner ear. J Neurosci. 2011; 31(19): 7178-89.

PubMed Abstract | Publisher Full Text | Free Full Text

136. Kopecky B, Santi P, Johnson S, et al:: Conditional deletion of $\mathbf{N}-\mathbf{M y c}$ disrupts neurosensory and non-sensory development of the ear. Dev Dyn. 2011; 240(6): 1373-90.

PubMed Abstract | Publisher Full Text | Free Full Text

137. Rand TA, Sutou K, Tanabe K, et al.: MYC Releases Early Reprogrammed Human Cells from Proliferation Pause via Retinoblastoma Protein Inhibition. Cell Rep. 2018; 23(2): 361-75 PubMed Abstract | Publisher Full Text

138. Pirvola U, Ylikoski J, Trokovic R, et al:: FGFR1 Is Required for the Development of the Auditory Sensory Epithelium. Neuron. 2002; 35(4): 671-80. PubMed Abstract | Publisher Full Text | Faculty Opinions Recommendation

139. Kersigo J, D'Angelo A, Gray $\mathrm{BD}$, et al: The role of sensory organs and the forebrain for the development of the craniofacial shape as revealed by Foxg1cre-mediated microRNA loss. Genesis. 2011; 49(4): 326-41. PubMed Abstract | Publisher Full Text | Free Full Text 